\title{
The study of moral games in educational markets
}

\begin{abstract}
Purpose: This study aims to explore the phenomenon, positive forces and facilitating approaches of moral games in educational markets as well as suppressed mechanisms against moral games in educational markets in secondary schools. The moral games in educational markets are defined as "when schools pursue self-interests in educational markets, their competitive and confrontational behavior responds to competitors' pressure, parents' consumption, and civil society based on ethical norms and the strategies derived."

Methods: This study applied the method of multiple case study and international comparison through field interview. The participants are five secondary school principals in Taiwan, USA, UK, Singapore and Australia. About the method of analysis, the researcher constructs the initial analytical framework by reviewing the literature. After acquiring the data of interview, the researcher analyses them with the initial analytical framework by comparison and interpretation, and discusses the meaning of the context.
\end{abstract}

Research Results: Firstly, when schools encounter competitive pressure from the educational markets, it will facilitate secondary schools to abide by ethical norms. Secondly, the positive forces of moral games in educational markets are to facilitate the innovation of schools, to intensify the interaction and cooperation between schools and communities, to establish positive public relation of schools and to help disadvantaged students. Thirdly, the suppressed mechanisms against moral games in educational markets are to neglect school members', parents' and students' needs, to facilitate school members' anti-professional behaviors and to overemphasize the utilitarian ethics. Fourthly, the facilitating approaches of moral games in educational markets are to pursue schools' excellent culture, to form cooperative networks among schools, and to build remarkable brands of schools.

Conclusion: This study supports the discourse that when schools face the competitive pressure in the educational marketization, they abide by the ethical norms and the strategies derived.

Keywords: Educational Markets; Moral Games; Secondary Schools
Volume I Issue I - 2017

\author{
Nai-Ying Whang \\ Department of Education, National Taiwan Normal University, \\ Taiwan
}

Correspondence: Nai-Ying, Department of Education, National Taiwan Normal University, Taiwan, Email t04014@ntnu.edu.tw

Received: July 31, 2017 | Published: August 28, 2017

\section{Introduction}

Educational marketization, the trend in educational systems, emphasizes that schools pursue self-interests and compete with others freely, and it has influenced school management in secondary schools particularly. ${ }^{1,2}$ When schools' behavior of competition and confrontation in the process of pursuing self-interests are ruled by ethical norms, schools can facilitate not only the games of morality in educational markets to achieve educational ideals..$^{3-5}$ However, even though schools uphold the value-neutral competitions of moral games in educational markets, they sometimes are likely to ignore the value of empathy and thus facilitate aloof relationship when facing the pressure of competition. ${ }^{6,7}$ Moreover, when facing the ethical conflict in the practice, school leaders tend to solve the dilemmas with effecitve ways, which might run the risk of going against their ethical responsibility to students. ${ }^{8}$ To avoid the harmful influences from the suppressed mechanism, there should be certain facilitative approaches to helping schools construct healthy ecology and deepen the ethical norms when facing the pressures from educational markets. ${ }^{9}$

Based on the contexts above, this study focused on the positive forces, suppressed mechanism, facilitative approaches of the moral games in educational markets and the researcher applied international comparison method to explore the phenomenon of moral games in educational markets in Taiwan, the United States, the United Kingdom, Singapore and Australia. At present, the educational competing system in Taiwan is filled with the phenomenon of control, which weakens the innovation of schools. And little attention is paid to moral issues of educational marketization. Therefore, this study tries to compare Taiwan and other four countries. Most of all, these constructive experiences from these countries may help Taiwan improve and learn more about the related issues, and manifest the positive ideals in educational markets for secondary schools.

\section{Research purposes}

According to the research background and motivation described above, purposes of this study are as follow:

a. To inquire the phenomenon of moral games in educational markets in secondary schools from Taiwan, the United States, the United Kingdom, Singapore and Australia.

b. To discuss the positive forces of moral games in educational markets from these five countries.

c. To analyze the suppressed mechanisms against moral games in educational markets from these five countries. 
d. To explore the facilitating approaches of moral games in educational markets from these five countries.

e. To provide secondary schools in these five countries with the suggestions about school management.

f. To inspire the new possibility of educational development in secondary schools in these five countries.

\section{Literature review}

\section{The concept of moral games in educational markets}

Educational marketization: Educational marketization is the trend in educational systems, and it has influenced school management in secondary schools particularly. There are both bureaucratic and competitive traits in educational systems. Therefore, educational systems are referred to as quasi-markets. ${ }^{10}$ In the process of marketization, the games of supplying and demanding interests in education systems drive schools to innovate the school management. ${ }^{11}$ In view of this, educational marketization not only strengthens organizational efficiency but ensures the quality of teaching and learning. ${ }^{12}$ In the context, schools may fulfill their moral purpose to create more responsibilities for school members and consolidate positive forces in the educational markets.

The concept of games: A "game" consists of a set of competitors who adopt strategies to pursue self interests. Competitors show their confrontational behaviors in the conflicts. Their choices of strategies determine consequences, which yield pay-offs to each competitor. ${ }^{13}$ In games, all competitors know the rules and information of the situations, and they will make decisions based upon maximizing their utility. ${ }^{14}$ In this process, competitors create the energy of new order and explore the order of social harmony at the same time. Therefore, "games" are defined as the "a series of confrontational or competitive behaviors respond to competitors' pressures, others' expectations and civil society when people pursues their interests."

Moral game of education market in schools: School organizations are educational systems related to ethics..$^{15}$ The competitions in educational markets are to realize moral goals, which mean that teachers can practice their missions of teaching. ${ }^{11}$ Moreover, school members carry out their own moral values ${ }^{16}$ and endeavor to transform resources in the social interaction process. In this way, school members can unite more members and resources to achieve the educational goals. ${ }^{17}$

About the concept of ethics, it concerns the search for a good "way of being", for a wise course of action..$^{18}$ In the Webster's international dictionary, ethic is defined as the discipline dealing with what is good and bad and with moral duty and obligation. ${ }^{19}$ The notions of moral and ethic are used interchangeably. In this research, the researcher considers morality and ethics as the same thing. Overall, the ethics of school organizations is defined as: School members practice the moral reflections in functional and marketing dimensions and abide by these moral forms as personal belief in order to guide their behaviors for responsibility in school.

To sum up, moral games in educational markets are defined as "when schools pursue self-interests in educational markets, their competitive and confronting behaviors respond to competitors' pressure, parents' consumption, and civil society based on ethical norms, and the strategies derived."

\section{The positive forces of moral games in educational markets}

The positive forces of moral games in educational markets are as follows. Firstly, when schools pursue interests, they build moral organizations with ethical foundation to make school strategies full of legitimacy and avoid lack of profession. In this way, more opportunities could be provided to ensure schools' development and innovation. ${ }^{20}$ Secondly, the moral games in educational markets enforce positive school marketing and emphasize teachers' and students' development to facilitate schools' efficiency. ${ }^{21}$ Thirdly, within the moral games in educational markets, school members have opportunities for reflection and problem-solving. In this way, it can facilitate the growth of school management and members. ${ }^{22}$ Fourthly, school members can realize that building moral organizations not only promotes the trust of community for schools but brings in more useful resources. ${ }^{23}$

\section{The suppressed mechanism against moral games in educational markets}

The following describes the suppressed mechanisms against educational moral games in educational markets. Firstly, the lack of profession and ethical belief for school members lead to greedy humanity. ${ }^{24}$ Secondly, when principal can't abide by professional ability and ethical values to face pressures, the school leadership is getting fragile. ${ }^{25,26}$ Also, ethical dilemmas arise when school leader's count on searching for efficient approaches to solve the collision of ethic norms related to stakeholders such as students, parents, and colleagues. ${ }^{8}$ Thirdly, if school management is based on the concept of free enterprise rather than educational professional ethics, it could lead to the results without social justice ${ }^{27}$ On the other hand, schools may use exaggerated even deceptive marketing strategies to get success in the competition ${ }^{28}$ In the end, anti-professional behaviors increase and suppress development of moral games in educational markets. ${ }^{29}$

\section{The facilitating approaches of moral games in educational markets}

The approaches facilitating the moral games in educational markets are as follows. Firstly, the government should construct an integrated policy to enrich the moral value in educational markets ${ }^{29}$ Secondly, School leaders should direct members to cooperate with others and facilitate positive environments for communication. ${ }^{23}$ Besides, democratic dialogue can encourage collaborative work toward a shared moral purpose concerning ethical practice. ${ }^{30}$ Finally, schools should pursue excellent quality to increase the moral properties. ${ }^{31,32}$ They may serve according to different demands from school members and ensure ethical materials for moral games to encourage school management with a variety of values.

\section{Research methods}

This study applied the method of qualitative multiple cases study and comparison method to inquire and compare the phenomenon of moral games in educational markets in secondary schools from several representative countries of specific areas. Moreover, this study focuses on the perspectives from the principal in Taiwan, and the data is compared with other four countries. The United States, the United Kingdom, Singapore, Australia and Taiwan are highly educational developed countries, and this was the main reason why this study chose them as the subjects. 
Principals are leaders of secondary schools, directing the administrative and teaching affairs of schools. Their perspectives on school management influence the development of schools holistically. As a result, the researcher chooses to collect the principals' ideas about moral games in educational markets.

Besides, the researcher adopted the method of field interview for 2-3 hours each time, and confirmed the content of interview through e-mail in advance. In the process of interviewing, an interview outline was used to help respondents express their ideas about this study. The interview outline explores principals' opinions about educational markets and moral values of marketing strategies.

The ways to contact with different respondents are as follows:

a. Taiwan: The researcher is subsidized by National Science Council in Taiwan to carry out a case study. One school in Taipei City, Taiwan is chosen as the subject of the case study. The researcher acquired opinions from the principal.

b. The United States of America: The school in the United States of America had language interaction with Ministry of Education, Taiwan, so the researcher had interview with one of five principals in Taipei City. The interview also focused on the discussion about excellent secondary schools in every state.

c. The United Kingdom: The researcher followed the international education delegation from Taiwan to the United Kingdom. On this visit, the researcher picked up one school which is suitable to be compared with school in Taiwan, and interviewed the principal.

d. Australia: The researcher got a project of National Science Council allowance for visiting Australia. The researcher interviewed three principals in Brisbane and chose one principal who shared more opinions.

e. Singapore: The researcher and a representative of the private school in Taipei City visited a competitive secondary school in Singapore.

Furthermore, based on the collected data, the introductions of the principals and schools are as Table 1.

Table I The introductions of the principals and schools

\begin{tabular}{|c|c|c|}
\hline Principal & Location & Introduction \\
\hline A & $\begin{array}{l}\text { Taipei, } \\
\text { Taiwan }\end{array}$ & $\begin{array}{l}\text { a. emphasis on students' multiple intelligences } \\
\text { b. provides various academic programs, } \\
\text { athletic activities } \\
\text { c. develops an excellent teachers' professional } \\
\text { learning environment }\end{array}$ \\
\hline B & $\begin{array}{l}\text { Virginia, } \\
\text { USA }\end{array}$ & $\begin{array}{l}\text { d. excellent school performance and } \\
\text { partnership with families and communities } \\
\text { e. provides multiple curriculums }\end{array}$ \\
\hline C & $\begin{array}{l}\text { Edinburgh, } \\
\text { UK }\end{array}$ & $\begin{array}{l}\text { f. strives to cooperate with communities } \\
\text { by promoting international teaching and } \\
\text { learning activities }\end{array}$ \\
\hline $\mathrm{D}$ & Singapore & g. acquires good reputation in public \\
\hline$E$ & $\begin{array}{l}\text { Brisbane, } \\
\text { Australia }\end{array}$ & $\begin{array}{l}\text { h. provides excellent academic, vocational and } \\
\text { cultural programs }\end{array}$ \\
\hline
\end{tabular}

To upgrade trustworthiness, this study constructed the basis of trust by strengthening the credibility, the transferability and the dependability of the data. Finally, the researcher hopes this research could expand international visions and promote the school reform by deliberating, discussing and analyzing in terms of different perspectives.

\section{Research results}

Based on the collected data, the following results are the comparison of schools from these five countries. The phenomenon of moral games in educational markets.

\section{Firstly, common discourses are as follows}

a. Principals are aware of ethical norms and strive to influence members to carry out these ethical norms in educational markets: School members can carry out the ethical norms in school's administration and teaching, and most importantly care for students' needs (the principal E).

b. When schools encounter competitive pressure from the educational markets, they abide by various ethical norms: .......even encountering the pressure from educational markets, our school still holds the core moral value of placing students' learning needs on the first place. In this way, our school's try to upgrade the quality of teaching and administration (The principal A).

\section{Secondly, the different discourses are as follows}

a. Taiwan emphasizes disadvantaged student' learning needs. The United States emphasizes help students of different cultures cooperate in studying: Our school provides disadvantaged students with adequate educational resources, hoping that students can have better development (the principal A). We offer admission to all county students, some students come from America's poorest and violent city while other areas are known as the most livable suburban towns in America; hence, the diversity is what makes our schools unique (the principal B).

b. Taiwan emphasizes students' divergent extracurricular activities in addition to their performance in exams. Singapore focuses on students' performance in exams: Undoubtedly, students' performance in exams is important for enrollment. However, our school still endeavors to cultivate students' interests in extracurricular activities such as music and sports (the principal A). We pay attention to students' learning performance such as GCE grades. Students' outstanding performance will attract parents' attention (the principal D).

c. Taiwan focuses on establishing the relation of cooperation with parents and communities. However, Australia promotes the core ethical norms in school administration in order to cultivate positive image: The cooperative relationship with communities strengthens our school development... Communities and schools are in a mutual beneficial network (the principal A). Our school reinforces the school motto, "Truth, Concord and Unity" on most occasions both in the school and to the wider school community (the principal E).

d. The principal in Taiwan owns the virtue of optimism, leading school members to upgrade learning efficiency. The principal 
in the United States owns the virtue of deliberation, improving the innovative school management: I always try to encourage teachers and students in a positive way.... In an atmosphere of trust and respect, teachers and students can have better performance (the principal A). School leaders should consider all aspects of school management and try to strengthen the quality of students' learning (the principal B). The positive forces of moral games in educational markets.

The common discourses are schools facilitate the innovation in teaching and administration and intensify the cooperation among schools and communities: Teachers in our school keep improving their professional skills and exchanging their teaching experiences. Therefore, students can get complete learning resources (the principal A). Our school pays much attention to parents' needs, community identification and builds a vision of world leader cultivation (the principal D).

\section{Secondly, the different discourses are as follows:}

a. Taiwan emphasizes to build positive public relations to acquire more resources. However, the United States emphasizes to establish concrete moral values and maintain positive public relation: Our school owns a group of supportive volunteers, who devoted their time and efforts. They are glad to engage in helping schools (the principal A). I believe that cooperation between schools and other organizations concerned with youth and education will enhance the opportunities of the district's pupils, and may enable the district to serve its pupils better through appropriate referrals (the principal B).

b. Taiwan provides appropriate learning aids and scholarship to students. Nevertheless, Australia provides equal learning opportunities for disadvantaged learners: In addition to helping disadvantaged students in teaching, teachers in our school even get united to provide disadvantaged students scholarships (the principal A). Our school provides equal learning opportunities for disadvantaged learners such as learners with disabilities. This is very reasonable in my opinion and I strongly support it as fairness is one of the most important moral issues (the principal E).

c. Taiwan stresses on establishing a balanced relation with other schools. Nevertheless, the United Kingdom cooperates with others in curriculum development and teachers' professional development: In the process of enrollment, we keep advocating the advantages of our school such as professional teachers, well-structured curriculums and various extracurricular activities (the principal $\mathrm{A}$ ). There are strong links with the state schools in our neighborhood. We co-operate in a wide range of areas - curriculum development, professional development, sharing good practice. Most important of all, we have a highly trained and innovative staff to provide students with variable learning resources (the principal C). The Suppressed mechanisms against moral games in educational markets. The common discourse is schools sometimes neglect the needs of teachers, parents and students when focusing on the shallow marketing strategies: When school doesn't have ideal result for enrollment, we may tend to overemphasize the school marketing for a better reputation. However, this decision may not take teacher's and student's needs into consideration (the principal D).

\section{Secondly, the different discourses are as follows}

a. In Taiwan, when there is a gap between school expertise and parental choice, it may facilitate school members' antiprofessional behaviors. In the United Kingdom, when the government can't establish the effective resource allocation system, the school with limited resources would increase irrational behaviors: In the trend of educational marketization, parents have lots of opportunities to express their opinions, even interfere school's decisions...I think teachers sometimes feel uncomfortable and feel their expertise is deprived (the principal A). Our links between the private and public sector are limited (The principal C).

b. Taiwan tends to overemphasize enrollment rather than create different values. In Singapore, the narrow channel to university not only encourages quality schools' arrogant behaviors but facilitates the aloof relationships among schools: Sometimes we put too many efforts to promote our enrollment and intellectual education; therefore it becomes another limitation for us (the principal A). In this country, not everyone can attend the university. The school with high GCE score sometimes shows the arrogant behaviors and seldom cooperates with other schools (the principal D).

c. In Taiwan, the competition within schools becomes intense after educational marketization. In Singapore, poor school efficiency makes bad sense of identity from parents and a few resources from government: The school administrators and teachers used to have negative interaction and our enrollment rate decreased. In that time, there was a bad school image from parents and community (the principal A). When our students' GCE scores weren't good enough, parents' sense of identity would decrease (the principal D). The facilitating approaches of moral games in educational markets. The common discourses are schools pursue their excellent culture and form cooperative networks with other schools or community: Our school connects well with the community by getting school students participating in events outside schools and helping out commuters (the principal E).

\section{Secondly, the different discourses are synthesized as follow}

a. Taiwan provides a variety of curriculums and activities for students with different backgrounds. However, the United Kingdom and Singapore both emphasize different curriculums and the implementation of international education: We develop lots of curriculums and activities to promote students' learning motivation; furthermore, they could learn different values through these activities (the principal A). We strive to offer international education such as immersion courses to our students (the principal D).

b. Taiwan arouses positive behaviors about parental choice while the United States and United Kingdom emphasize parents' rights: We often encourage parents to attend lectures including topics of family, parental education (The principal A). Our families are pleased with the education their children receive and have an avenue for expressing displeasure should that occur. There are many opportunities for parents to participate in committees and advisory boards so that the school board can gain their input (the principal B). 


\section{Discussion}

\section{According to the discourses above, here are some discussions}

\section{The phenomenon of moral games in educational markets}

Taiwan and the other four countries have some similarities in phenomenon of moral games in educational markets (Table 2). Firstly, principals are aware of ethical norms and strive to facilitate moral games in educational markets. The competitive behaviors tend to be rational if schools can carry out ethical norms. ${ }^{33}$ Secondly, when schools encounter competitive pressure from educational markets, it will facilitate schools to abide by ethical norms such as empathy, justice, equity, utility, expertise, diversity and innovation. These ethical norms contribute to facilitating the moral traits of educational markets. $^{34}$

However, there are some differences in Taiwan and other countries (Table 2). Firstly, about the ethics of care, Taiwan emphasizes the care for disadvantaged students, especially in the dimension of students' learning needs. The United States emphasizes cross-cultural students' cooperation to strengthen the equality of educational opportunities. Compared to Taiwan, the United States shows consideration for crosscultural students, which could be an important implication for schools in Taiwan. Therefore, the above examples show that schools facilitate the moral traits of educational markets through abiding by the ethics of care. ${ }^{4}$

Secondly, about the utilitarian ethics, Taiwan emphasizes students divergent extracurricular activities in addition to their performance in exams. Singapore focuses on students' performance in exams, and students' great performance in exams contributes to schools' enrollment. When schools encounter the competitive pressure of education markets, they strengthen the efficiency of school management, especially in students' learning achievement. That is to say, moral games in educational markets can facilitate schools' efficiency and upgrade schools' productivity. ${ }^{35,36}$

Thirdly, concerning the relation with communities, Taiwan focuses on establishing the relation of cooperation with students' parents and communities. In this way, schools can get more related resources. In addition to abiding by the core ethical norms, Australia promotes the core ethical norms in school administration in order to cultivate positive image. Moral games in educational markets emphasize that schools endeavor to operate as a moral organization, which arouses people's trust in school. ${ }^{23}$ In this way, the legitimacy of school management is strengthened, and the public are motivated to provide their assistance to schools ${ }^{37}$ As a result, good interaction with communities and positive images can bring school more important educational resources. ${ }^{35}$

Fourthly, about the characteristics of leaders, Taiwan and the United States show different traits, which influence school members and organizations. The principal in Taiwan owns the virtue of optimism. Under the pressure from educational markets, the positive virtue leads school members to achieve the goals of school management and to upgrade students' learning efficiency. The principal in the United States owns the virtue of deliberation, which improves the innovative strategies of administrative and teaching. School leaders play coordinating roles and make all members cooperate with each other ${ }^{38}$ In addition, making logical decisions, care for the feelings of individuals and manage positive atmosphere of the organization can facilitate effective leadership. ${ }^{39}$
Table 2 The phenomenon of moral games in educational markets

\begin{tabular}{|c|c|}
\hline Country & Content \\
\hline \multirow{4}{*}{ Taiwan } & $\begin{array}{l}\text { a. The leader can abide by the value of love, integrity and } \\
\text { harmony. It will contribute to school innovation. } \\
\text { b. b. Members can abide by the moral value of "no child left } \\
\text { behind," which strengthen inner utility. }\end{array}$ \\
\hline & $\begin{array}{l}\text { c. The process of strengthening care for disadvantaged } \\
\text { students can consolidate the realization of educational } \\
\text { mission. }\end{array}$ \\
\hline & $\begin{array}{l}\text { d. Strengthening the values of utility and diversity } \\
\text { contributes to the enrollment. }\end{array}$ \\
\hline & $\begin{array}{l}\text { e. The leader owns the virtue of optimism, which contribute } \\
\text { to promoting school effectiveness. }\end{array}$ \\
\hline \multirow{3}{*}{$\begin{array}{l}\text { The } \\
\text { United } \\
\text { States }\end{array}$} & $\begin{array}{l}\text { f. The school helps students from different cultures } \\
\text { cooperate in studying to strengthen the equality of } \\
\text { educational opportunities. }\end{array}$ \\
\hline & g. The leader owns the virtue of deliberation. \\
\hline & $\begin{array}{l}\text { h. The school abides by the value of equity and facilitates } \\
\text { the reform of organization. }\end{array}$ \\
\hline $\begin{array}{l}\text { United } \\
\text { Kingdom }\end{array}$ & $\begin{array}{l}\text { i. The schools strengthen the ethics of care and facilitate } \\
\text { learning cooperation among cross-cultural students in } \\
\text { order to provide equal opportunity of education. }\end{array}$ \\
\hline \multirow[t]{2}{*}{ Singapore } & $\begin{array}{l}\text { j. The school intensifies utilitarian ethics. For example, } \\
\text { school's image will be promoted if students' GCE grades } \\
\text { are outstanding. }\end{array}$ \\
\hline & $\begin{array}{l}\text { k. The schools construct their core moral values, and } \\
\text { promotes these moral values in the administrative affairs } \\
\text { of schools in order to cultivate the positive social image } \\
\text { of school. }\end{array}$ \\
\hline Australia & $\begin{array}{l}\text { I. The school abides by the moral values of diversity, } \\
\text { respect, equity, honesty, cooperation and harmony in } \\
\text { order to facilitate schools' innovation. }\end{array}$ \\
\hline & $\begin{array}{l}\text { m. The school interacts with students' parents and } \\
\text { communities. }\end{array}$ \\
\hline
\end{tabular}

The positive forces of moral games in educational markets, Taiwan and the other four countries have some similarities in positive forces of moral games in educational markets (Table 3). Firstly, schools innovate the content of teaching and administration such as promoting school members' professional development. Thus, the moral games in educational markets help schools develop and improve the content of education that they provide in innovative ways. ${ }^{40}$ Secondly, moral games in educational markets facilitate the moral traits and awareness of schools, and thus schools endeavor to operate as moral organizations. In this way, the public are willing to contribute their efforts to helping schools.

There still are differences existing in Taiwan and other countries (Table 3). Firstly, moral games in educational markets strengthen schools' public relations. Taiwan emphasizes that establishing positive public relation helps schools acquire resources. The United States emphasizes that schools have to establish concrete moral values and maintain their positive public relations. That is to say, schools immerse the moral values in the educational markets and endeavor to establish a positive educational environment. ${ }^{34}$ Moral games in educational markets stress that schools try to implement the process of democratic participation through connecting school members 
and students' parents. In this way, students' parents are facilitated to provide mutual contributions to schools.

Table 3 The positive forces of moral games in educational markets

\begin{tabular}{|c|c|}
\hline Country & Content \\
\hline \multirow{4}{*}{ Taiwan } & $\begin{array}{l}\text { a. The school strengthens teachers' professional abilities to } \\
\text { promote the school's enrollment. } \\
\text { b. The school establishes cooperative relation with } \\
\text { communities and neighborhoods. }\end{array}$ \\
\hline & $\begin{array}{l}\text { c. Establishing positive public relation helps the school } \\
\text { acquire resources. }\end{array}$ \\
\hline & $\begin{array}{l}\text { d. The school provides appropriate teaching and learning } \\
\text { aids as well as scholarship to students. }\end{array}$ \\
\hline & $\begin{array}{l}\text { e. The school establishes a balanced relation with other } \\
\text { schools. }\end{array}$ \\
\hline \multirow[t]{2}{*}{$\begin{array}{l}\text { The } \\
\text { United } \\
\text { States }\end{array}$} & $\begin{array}{l}\text { f. The school establishes concrete moral values and } \\
\text { maintains their positive public relations. }\end{array}$ \\
\hline & $\begin{array}{l}\text { g. The school has highly trained and innovative staff to } \\
\text { develop a wide range of curriculums and extra-curricular } \\
\text { activities. }\end{array}$ \\
\hline \multirow[t]{2}{*}{$\begin{array}{l}\text { The } \\
\text { United } \\
\text { Kingdom }\end{array}$} & $\begin{array}{l}\text { h. The school has strong links with the local community to } \\
\text { maintain their positive relationship. }\end{array}$ \\
\hline & $\begin{array}{l}\text { i. The school cooperates with other schools in many } \\
\text { ways such as curriculum development and teachers' } \\
\text { professional development. }\end{array}$ \\
\hline Singapore & $\begin{array}{l}\text { j. The school builds a vision of world leader cultivation in } \\
\text { response to parents' needs and community identification. }\end{array}$ \\
\hline \multirow[t]{2}{*}{ Australia } & $\begin{array}{l}\text { k. The school cares for disadvantaged students' learning } \\
\text { needs, and provides them with adequate educational } \\
\text { resources and opportunities. }\end{array}$ \\
\hline & $\begin{array}{l}\text { I. Schools provide students with equal learning } \\
\text { opportunities to strengthen students' learning right. }\end{array}$ \\
\hline
\end{tabular}

Secondly, moral games in educational markets inspire schools to care about disadvantaged students. Taiwan provides appropriate teaching and learning aids as well as scholarship to students. Thus, disadvantaged students can learn under sufficient educational contents. In Australia, the school provides equal learning opportunities for learners with disabilities. In a word, practicing moral games in educational markets helps schools endeavor to fulfill social responsibility. ${ }^{34}$ Schools' awareness of love and care about students are aroused. They strive for fulfilling students' learning needs. Therefore, students' learning opportunities are enlarged.

Thirdly, moral games in educational markets activate interaction among schools and make schools maintain a balanced relationship. ${ }^{11}$ The school in Taiwan endeavors to advocate their own advantages while not to talk about other schools' weakness. In the United Kingdom, schools cooperate in curriculum development and teachers' professional development. Moral games in educational markets emphasize that schools operate as moral organization and try to carry out social responsibilities. Thus, schools are willing to share the strategies of school management with others. ${ }^{41}$ In this way, schools can find more educational resources to develop their own distinguishing features.

\section{The suppressed mechanisms against moral games in educational markets}

In this dimension, there are some similarities and differences between Taiwan and other countries (Table 4). Firstly, both the focus on school marketing and utilitarian ethics makes some schools members' needs are neglected in Taiwan and Singapore. In other words, educational marketization promotes the school accountability as well as realizes moral values to ensure the rights of school members. ${ }^{11}$ If schools only pursue the school accountability, educational marketization would weaken the social justice and the value of equity in schools. ${ }^{42,43,44}$ Some schools have excessive pursuit of efficiency and the middle-class parents participate in school affairs overly. ${ }^{45}$ Finally, education gradually becomes nothing but serves certain parents and students ${ }^{46}$ and restricts the development of moral games in educational markets.

Table 4A The suppressed mechanisms against moral games in educational markets

\section{Country Content \\ a. When school endeavors to promote school marketing, some teachers have doubt about the necessity. \\ b. There is a gap between school expertise and parental choice, and it facilitates school members' anti-professional behavior. \\ Taiwan \\ c. After educational marketization, the school development is limited on certain ethical foundation, such as utilitarian ethics. \\ d. The intense competition within schools may influence school culture. \\ The e. When the school with limited resources faces competitive United behaviors, it tends to use vainglorious marketing strategies States to deal with. \\ The \\ United \\ Kingdom \\ f. When the government is unable to establish the effective resource allocation system, the school with limited resources would increase irrational and anti-professional behavior. \\ g. When the school's management doesn't meet government' $s$ expectation and parents' needs, school's marketing strategies tend to become apparent. \\ Singapore \\ h. The narrow channel to university not only encourages quality school's arrogant behaviors but also facilitates the aloof relationships among schools. \\ Australia \\ i. When school's management ideals doesn't correspond to the market trend, it weakens customers' trusts.}

Secondly, the findings indicated that schools after educational marketization raise irrational behaviors owing to some reasons. For example, Taiwan has struggle between teachers' expertise and parents' choices; parents' excessive interference in school affairs sometimes result in conflicts among teachers and parents. As a result, teachers often have insecurity and their teaching skills are limited by certain parents. ${ }^{47}$ The insincere behaviors make schools neglect educational purpose. ${ }^{48}$ On the other hand, in United Kingdom and the United States, the school members' irrational behaviors increase because of scattered resources. When keen competition among schools occurs, there are irrational communicative behaviors. ${ }^{49}$ Finally, the irrational behaviors not only diminish positive relation among schools and communities but limit professional development. ${ }^{50}$ 
Table 4B The facilitated approaches of moral games in educational markets

$$
\begin{aligned}
& \text { Country Content } \\
& \text { a. The school builds particular characteristic to strengthen } \\
& \text { school marketing and innovation. }
\end{aligned}
$$

s. The school emphasizes students' profits and regards it as core value for school members to follow

All in all, in the moral games of educational markets, principals sometimes have to strike a balance between the management of moral organization and the emphasis of utilitarianism..$^{51,52}$ However, when there are some aggressive behaviors in competitions, the negative behaviors may easily damage the schools' climate and restrain the teachers' expertise. ${ }^{53,47}$ Moreover, if school leaders only seek for effective solutions to deal with the conflict, the risk of against ethical practice will become higher. ${ }^{8}$ Therefore, it is important for schools that the competitive behaviors should combine the virtue of reflection with utilitarianism to ensure positive moral games in educational markets.

\section{The suppressed mechanisms against moral games in} educational markets

The facilitating approaches of moral games in educational markets: Taiwan and the other four countries have some similarities and differences in facilitating approaches of moral games in educational markets (Table 5). Firstly, the school in Taiwan has high enrollment rate and this becomes a major factor to influence parents to choose. Otherwise, enrollment rate, school curriculums and interaction with community are important factors for parents to choose in other countries. As the finding shows, the school community is a bridge to promote schools' advantages; the schools' image and reputation would spread through community. When resources and contribution from community increase, it facilitates more people participate in the schools' development and makes moral games in educational markets flourish. ${ }^{54,55}$

Secondly, Taiwan and other countries provide a wide variety of curriculums for students. For example, Taiwan pays attention to multiple activities as well as intellectual education to cultivate students' various abilities. Otherwise, findings indicated schools from other four countries especially develop a variety of cross-cultural curriculums to expand interaction with schools all over the world. When the school provides multiple curriculums, it enlarges the educational opportunities for students through the process of coordination. ${ }^{56} \mathrm{Lim}^{57}$ also found that multiple curriculums help schools create an abundant environment for moral games in educational markets.

Finally, the school in Taiwan especially focuses on parent education to arouse positive behaviors about parental choice. The school in Taiwan has held lots of activities and lectures to help parents' growth. On the other hand, the schools in the United Kingdom and United States emphasize parents' participation and encourage them to share opinions about school management. ${ }^{58}$ Mentioned that when schools construct the partnership with parents and establish a reciprocal support system, the school management could avoid being controlled by irrational behavior from parents. ${ }^{59,60}$ Moreover, the interaction between schools and parents would arouse the reflective motivation of school management and promote schools to pursue positive moral games in educational markets. ${ }^{61,62}$ These collaborative dialogic processes can include voices of educational partners, and further engage in critical reflection and discussion, fostering the adoption as well as the practice of the post-modern governance and the ethic of social justice. ${ }^{8,63}$

\section{Conclusion, suggestions and implication}

This study supports the discourse that when schools face the competitive pressure in the educational marketization, secondary schools in the United States, the United Kingdom, Singapore, Australia and Taiwan abide by the ethical norms and the strategies derived. We conclude that moral games of educational marketization may arouse school members' moral conscience when pursuing self-interests, facilitate schools to strike a balance between schools' excellence and equity, strengthen schools' ethical norms to avoid school corruption, enrich school members' expertise and positive behavior, emphasize the successful communication and partnerships among different organizations, and arouse school members' passion and commitment to education in order to strive for educational development. 
Based on the integrated research results, there are several suggestions for secondary schools all over the world in general and Taiwan in particular to apply. Firstly, the following suggestions are for worldwide secondary schools.

a. School leaders and members should abide by various ethical norms and immerse these ethical norms into school affairs to develop the positive environments of educational markets.

b. Schools should innovate schools' management, promote school members' professional development, and import external resources to strengthen the positive forces in educational markets. As a result, when schools pursue interests, they can create all kinds of approaches and opportunities to explore new knowledge and skills of moral games in educational markets.

c. Schools should strike a balance between school accountability and disadvantaged students' needs to avoid the suppressed forces in educational markets. That is to say, when schools pursue interests, they can cultivate moral values to construct healthy ecology of moral games in educational markets.

d. Schools should establish excellent culture, form cooperative networks among schools, and build remarkable brands of schools to facilitate positive educational markets. In other words, when schools pursue interests, they can create the core traits of the moral games in educational markets based on the brands and culture.

\section{Secondly, the following suggestions are provided for secondary schools of Taiwan in particular}

a. School leaders should establish correct cognition towards ethic norms and strive to inspire members to practice these ethic norms in the process of school management. As a result, when schools pursue interests, they can establish moral organizations and make precise judgments on the issues of moral games in educational markets.

b. Schools should cultivate the positive and sharing culture of organization to facilitate members' cooperation and professional development. That is to say, when schools pursue interests, they can transform the forces of markets into the forces of improvement.

c. Schools should broaden the communicative networks to timely respond to members' needs. In this way, schools can perform adequately in all dimensions of school management. As a result, when schools pursue interests, they can facilitate reasonable discourse and keep constructing the order of moral games in educational markets.

Finally, relevant advice induced from this study will be provided for the secondary schools and future researchers' reference for exploring the issues of moral games in educational markets. About the implications for future researches, researchers can adopt crosscultural study to explore deeper related issues. Moreover, about the implications particularly for Taiwan, under the trend of educational marketization, schools should cultivate the foundation of moral games in educational markets, and endeavor to implement them in educational fields.

\section{Acknowledgements}

None.

\section{Conflict of interest}

The author declares no conflict of interest.

\section{References}

1. May JJ. The market-driven age of education: Challenge of Urban School leadership. Mid-Western Educational Researcher. 2007;20(4):28-34.

2. http://foreignpolicy.com/

3. Goodman JF, Lesnick H. The moral stake in education: Contested premises and practices. Longman, New York, USA; 2001.

4. Halstead JM. Values and values education in schools. In: JM Halstead, Monica JT, editors. Values in education and education in values. London: The Falmer Press; 1996. p. 3-14.

5. Hayek F. Law, legislation and liberty. In: Kegan Paul, editor. Routledge, London; 1976.

6. Arnsperger C, Ville P de. Can competition ever fair? Challenge the standard prejudice. Ethical Theory and Moral Practice. 2004;7(4):433451.

7. Magill G, Prybil L. Stewardship and integrity in health care: A role for organizational ethics. Journal of Business Ethics. 2004;50:225-238.

8. McGee JW, Mansfield KC. Negotiating the double mandate: Mapping ethical conflict experienced by practicing educational leaders. NCPEA Education Leadership Review of Doctoral Research . 2014;1(1):157-174.

9. Robin DP, Reidenbach R. Searching for a place to stand: Toward a workable ethical philosophy for marketing. Journal of Public Policy \& Marketing. 1993;12(1):97-106.

10. Vandenberghe V. Combining market and bureaucratic control in education: An answer to market and bureaucratic failure? Comparative Education. 1999;35(3):271-282.

11. Bates R. Morals and markets: Adam Smith's moral philosophy as a foundation for administrative ethics. In: AS Eugenie, editor. Ethical Foundations for Educational Administration. New York, USA; 2003. p. 95-125.

12. Apple MW. Creating profits by creating failures: Standards, Markets, and inequality in education. International Journal of Inclusive Education. 2001;5(2):103-118.

13. Camerer CF. Does strategy research need game theory? Strategic Management Journal. 1991;12:137-152.

14. Herbig PA. Game theory in marketing: applications, uses and limits. Journal of Marketing Management. 1991;7:285-298.

15. Tarc AM. In a dimension of height: Ethics in the education of others. Educational Theory. 2006;56(3):287-304.

16. Freeman SJ, Engels DW, Altekruse MK. Foundations for ethical Standard and codes: The role of moral philosophy and theory in ethics. Counseling and Values. 2004;48:163-173.

17. Blanke V. Organizational theory: Doctor Core. Columbus, The Ohio State University, USA; 1992.

18. Badiou A. Ethics: An essay on the understanding of evil. Verso, New York, USA; 2001.

19. Grove. Webster's third international dictionary. Springfield, MerrianWebster, USA; 1986.

20. Clarke P, Gray D. The marketing curriculum and educational aims: toward a professional education? Marketing Intelligence \& Planning. 2006;24(3):189-199.

21. Arnett DB, Hunt SD. Competitive irrationality: The influence of moral philosophy. Business Ethics Quarterly. 2002;12(3):279-303. 
22. Boyd WL, Walberg HJ. Introduction and overview. In: WL Boyd, HJ Walberg, editors. Choice in education. McCutchan, Berkeley, California USA; 1990.

23. Fourcade M, Healy K. Moral views of market society. The Annual Review of Sociology. 2007;33:285-311.

24. Makowitz HM. Markets and morality. The Journal of Portfolio Management. 1992;18(2):84-93.

25. Oplatka I, Foskett N, Hemsley-Brown J. Educational marketization and the head's psychological well-being: A speculative conceptualization. British Journal of Educational Studies. 2002;50(4):419-441.

26. Shleifer A. Does competition destroy ethical behavior? Journal of Contemporary Legal Issues. 2004;17:8-32.

27. Menashy F. The end of efficiency: Implications for democratic education. Journal of Educational Thought. 2007;41(2):165-177.

28. Hesketh AJ, Knight PT. Secondary school prospectuses and educational markets. Cambridge Journal of Education. 1998;28(1):21-35.

29. Hyland T. Professionalism, ethics and worked-based learning. British Journal of Educational Studies. 1996;44(2):168-180.

30. Smith D M, Qua-Hiansen J. Democratic dialogue as a process to inform public policy: Reconceptualizing a supervisory officer's qualification program. International Journal of Education Policy and Leadership. 2015;10(1):1-32.

31. Marshland D. Markets and the social structure of morality. Society. 2001;26(1):33-38

32. Peters T, Waterman R. In search of excellence. Random House, New York, USA; 1982.

33. Kaneff D. The shame and pride of market activity: Morality, identity in post-socialist rural Bulgaria. In: R Mandel, C Humphrey, editors. Markets \& morality: Ethnographies of post-socialism. Berg, New York, USA; 2002. p. 33-51.

34. Marshall C. Social justice challenge to educational administration: Introduction to a special issue. Educational Administration Quarterly. 2004;40(1):3-13.

35. Blanke V. Understanding organization. Columbus, The Ohio State University, USA; 1991.

36. Buurma H. Public policy marketing: Marketing exchange in the public sector. European Journal of Marketing. 2001;35(11):1287-1300.

37. Jeffrey R Henig. Rethinking school choice: Limits of the market metaphor. NJ: Princeton University Press, Princeton, USA; 1994.

38. Everett J S. Ethics education and the role of the symbolic market. Journal of Business Ethics. 2007;76(3):253-267.

39. Gage T, Smith C. Leadership intelligence: Unlocking the potential for school leadership effectiveness. South African Journal of Education. 2016;36(4):1-9.

40. Carl Bagley C. School choice and competition: A public-market in education revisited. Oxford Review of Education. 2006;32(3):347-362.

41. Dow EH. Successful Inter-institutional Resource Sharing in a Niche Educational Market: Formal Collaboration without a Contract Innovation Higher Education. 2008;33(3):169-179.

42. Beck J. Morality and citizenship in education. Cassell, London; 1998.

43. Cui G, Choudhury P. Consumer interests and ethical implications of Marketing: A contingency framework. The Journal of Consumer Affairs. 2003;37(2):364-387.
44. Macfarlane B. Business ethics and the role of pride. Management Education and Development. 1993;24(4):309-315.

45. Marginson S. Dynamics of national and global competition in higher education. Higher Education. 2006;52:1-39.

46. Abela AV, Murphy PE. Marketing with integrity: Ethics and the servicedominant logic for marketing. Journal of the Academy of Marketing Science. 2008;36(1):39-53.

47. Lipton L. Transforming information into knowledge: Structured reflection in administrative practice. 1993:ED361903.

48. Eckel PD. Redefining competition constructively: The challenges of Privatization, competition and market-based state policy in United States. Higher Education Management and Policy. 2007;19(1):93.

49. Apple MW. Educating the "right" way. USA: Routledge; 2006.

50. House ER. Schools for sale: Why free market policies won't improve America's schools, and what will. Teachers College, USA: Columbia University Press; 1998.

51. Judisch N. Responsibility, manipulation and ownership: Reflections on the Fischer/Ravizza program. Philosophical Exploration. 2005;8(2):115130.

52. Williams WE. The argument for free market: Morality vs. efficiency. Cato Journal. 1996;15(2-3):179-189.

53. Hawks VD, Benzley SE, Terry RE. Establishing ethics in an organization by using principles. Science and Engineering. 2004;10(2):259-267.

54. Akaah IP, Riordan EA. Judgment of marketing professionals about ethical issues in marketing research: A replication and extension. Journal of Marketing Research. 1989;26(1):112-120.

55. Winch C, Gingell J. Philosophy \& educational policy: A critical introduction. USA: Routledge; 2004.

56. Michaela Driver. Beyond the stalemate of economics versus ethics: Corporate social responsibility and the discourse of the organizational self. Journal of Business Ethics. 2006;66:337-356.

57. Lim L, Tan J. The marketization of education in Singapore: Prospects for inclusive education. International Journal of Inclusive Education. 1999;3(4):339-351.

58. Lauder H, Hughes D. Trading in futures: Why markets in education don't work. Buckingham, PA: Open University Press, UK; 1999.

59. De Mesquita BB. Game theory, political economy, and the evolving study of war and peace. American Political Science Review. 2006;100(4):637642.

60. Dunfee TW, Smith NC, Ross WT. Social contracts and marketing ethics. Journal of Marketing. 1999;63(3):14-32.

61. Geva A. A typology of moral problems in business: A framework for Ethical Management. Journal of Business Ethics. 2006;69(2):133-147.

62. Hoffman L, Burrello LC. A case study illustration of how a Critical theorist and $\mathrm{s}$ consummate practitioner meet on common ground. Educational Administration Quarterly. 2004;40(2):268-289.

63. Carlile A. 'Critical bureaucracy' in action: Embedding student voice into school governance. Pedagogy, Culture \& Society. 2012;20(3):393-412.

64. Heinze EA. commonsense morality and the consequentialist ethics. Of humanitarian intervention. Journal of Military Ethics. 2005;4(3):168182.

65. Smith A. The theory of moral sentiments. England: Cambridge University Press; 2002. 